\title{
The Effects of Sildenafil Citrate (Viagra) in the Early Phase of Healing Process in Open Wounds in Dogs
}

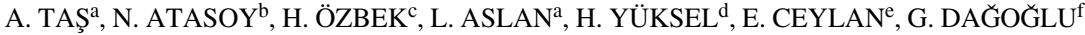 \\ Departments of Veterinary ${ }^{\text {a Surgery, }}{ }^{\mathrm{d}}$ Pathology, ${ }^{\mathrm{e}}$ Internal Medicine, \\ fPharmacology, Veterinary Faculty, Yuzuncu Yil University, Van, Turkey \\ ${ }^{\mathrm{b}}$ Department of Veterinary Surgery, Veterinary Faculty, Ataturk University, Erzurum, Turkey \\ ${ }^{c}$ Department of Pharmacology, Medical Faculty, Yuzuncu Yil University, Van, Turkey
}

Received July 16, 2002

Accepted March 25, 2003

\begin{abstract}
Taş A., N. Atasoy, H. Özbek, L. Aslan, H. Yüksel, E. Ceylan, G. Dagoglu: The Effects of Sildenafil Citrate (Viagra) in the Early Phase of Healing Process in Open Wounds in Dogs. Acta Vet. Brno 2003, 72: 273-277.

In vivo $(\mathrm{n}=16)$ and in vitro $(\mathrm{n}=16)$ experiments were conducted in dogs to describe the effects of sildenafil citrate (viagra) on histopathological changes during the healing process with respect to angiogenesis and compare vasodilatative effects of sildenafil citrate, acetylcholine and sodium nitroprusside. General anaesthesia was performed with $0.2 \%$ ketamine $\mathrm{HCl}$ by intravenous drip after premedication with xylazine $\left(5 \mathrm{mg} \cdot \mathrm{kg}^{-1}\right)$ and atropine sulphate $\left(0.05 \mathrm{mg} \cdot \mathrm{kg}^{-1}\right)$. Round open wounds were created in all skin layers on anterior brachial region in all animals. On days 1, 3,5 and 7 following the operation sildenafil citrate $(25 \mathrm{mg})(\mathrm{n}=8)$ and saline $(\mathrm{n}=8)$ were orally administered. Wound tissues were dissected for histological observation on days 3,6 , and 9 . Animals receiving sildenafil citrate had greater granulosa tissue more apparent capillary network and greather fibroblast proliferation than control group on day 6 . Vasorelaxant effects of sildenafil citrate, acetylcholine and sodium nitroprusside on a. brachialis were investigated in vitro. In this study, relative vasorelaxant effects of sildenafil citrate, acetylcholine and sodium nitroprusside were 4.91, 5.75 and 6.70, respectively. Results of this study suggest that sildenafil citrate does enhance the healing process by stimulating angiogenesis.
\end{abstract}

Trauma, vasodilatation, angiogenesis, regeneration, vasorelaxation, experimental approach

Wound healing is a complex chain of cellular and biochemical events designed to restore tissue integrity and function. There are two stages as major components of wound healing in the early phase. The first stage is the inflammatory stage. The second one is the new tissue formation. In the inflammatory stage, various inflammatory cells such as polymorph nuclear neutrophil (PMN) cells and macrophages infiltrate the injured area. At the new tissue formation stage, fibroblasia begins by the formation of granulation tissue within the wound space. This tissue consists of a loose matrix of collagen, fibronectin and hyaluronic acid (Ringler 1997).

Angiogenesis plays a major role in adult tissue repair and remodelling. It is critical in wound healing, bone repair, ischemic heart (Folkman and Shing 1992). Sodium nitroprusside activators of constitutive nitrous oxide synthase (NOS) and nitrous oxide (NO) donors promote endothelial cell proliferation and migration. These responses are suppressed by NOS inhibitors ( $\mathrm{Ziche}$ et al. 1994). Also monocyte-induced angiogenesis requires an Larginine/NOS-dependent mechanism (Leibovich et al. 1994). These data suggest that NO and vasodilatation are necessary for angiogenesis. Sildenafil citrate has no direct relaxant effect, but enhances the effect of NO by inhibiting phosphodiesterase type 5 (PDE5), which is responsible for degradation of cyclic guanosine monophosphate (cGMP). Inhibition of PDE5 by sildenafil citrate causes increased levels of cGMP, resulting in smooth muscle relaxation. PDE5 is found in platelets, vascular and visceral smooth muscles, and skeletal muscles (Anonymous 1988). Increased vascular permeability occurs during the early phases of wound repair, theoretically allowing deposition of the fibrin-rich matrix necessary 
for cellular migration and proliferation (B row $\mathrm{n}$ et al. 1988). Both normal and injured cells of many types, including neurons, muscle cells, neutrophil and macrophages, can generate NO by the breakdown of L-arginin via the NOS pathway (S te wart et al. 1994).

The current literature have mainly been focuced on biochemically events in healing process. However, studies concerning effects of vasodilatative agents on wound healing is limited.Therefore, the present study was performed to elucidate the role of sildenafil citrate in wound healing histopathologically.

\section{Materials and Methods}

Both in vivo and in vitro work were approved by the Medical Research Ethics Committee of Yuzuncu Yil University Research Hospital.

Experiment I: In vivo study

Sixteen healthy female cross-breed street dogs weighing 15-20 kg and aged 1-3 years were allocated randomly to two groups of eight. The animals were housed in individual cages at the research hospital of the University of Yuzuncu Yil, Faculty of Veterinary Medicine, fed daily convenient foods and allowed free acces to water throughout the study. The animals were acclimatized for two week prior to study.

General anaesthesia was performed with $0.2 \%$ ketamine $\mathrm{HCl}$ by intravenous drip after premedication with xylazine $\left(5 \mathrm{mg} \cdot \mathrm{kg}^{-1}\right)$ and atropine sulphate $\left(0.05 \mathrm{mg} \cdot \mathrm{kg}^{-1}\right)$. Each dog was then placed in lateral position and prepared for aseptic surgery. Round open wounds at the size of $2 \mathrm{~cm}$ in diameter were created across all skin layers on anterior brachial region by a blade. All wound were covered with nonadhernt occlusive bandage. Bandage was changed every 3 days. On days 1, 3, 5 and 7 following the operation, sildenafil citrate $(25 \mathrm{mg})$ and saline were orally administrated to the experimental and the control group.

Wound tissues were dissected for histological observation on days 3, 6 and 9 relative to inducing wound under general anaesthesia. The tissues were fixed in $10 \%$ neutral buffered formalin and stained with haematoxylin-eosin (HE) for van Gieson's collagen fibers for histological examination.

Experiment II: In vitro study

$\operatorname{Dogs}(\mathrm{n}=16)$ were anesthetized with pentobarbital sodium $\left(20 \mathrm{mg} \cdot \mathrm{kg}^{-1}\right)$. A segment of a. brachialis was removed immediately, the vessel was anastomosed by virgin silk (\# 8-0). The dogs were kept under control until full recovery (about $10 \mathrm{~d}$ ).

Samples of a. brachialis were cut into rings approximately $4 \mathrm{~mm}$ wide, mounted on steel hooks, and immersed in aerated Krebs solution maintained at $37^{\circ} \mathrm{C}$. Isometric responses were recorded by strain gauge transducers connected to a polygraph. A 2 resting tension was applied, and the a. brachialis rings were then contracted with phenylephrine $\left(3.10^{-6} \mathrm{M}\right)$, a concentration that had previously been shown to produce a submaximal contraction on the linear portion of the dose-response curve (approximately 60\%). When this response had stabilized, the presence of a functional endothelium was assessed by the ability to elicit relaxation of the muscle by addition of acetylcholine $(1.0 \mathrm{~m} \mathrm{M})$.

Each ring of a. brachialis was immersed in a $15 \mathrm{ml}$ tissue bath containing a continously oxygenated $\left(95 \% \mathrm{O}_{2}, 5 \%\right.$ $\mathrm{CO}_{2}$ ) Krebs solution at $37^{\circ} \mathrm{C}$ and a $\mathrm{pH}$ of 7.4. The solution consisted of $6.90 \mathrm{~g} \mathrm{NaCI}, 2.10 \mathrm{gr} \mathrm{NaHCO}_{3}, 0.34 \mathrm{gr} \mathrm{KCI}$, $0.16 \mathrm{~g} \mathrm{KH}_{2} \mathrm{PO}_{4}, 0.30 \mathrm{~g} \mathrm{MgSO}_{4}, 2.00 \mathrm{~g} \mathrm{D}$-glucose and $0.18 \mathrm{~g} \mathrm{CaCI}_{2}$ in 1 litre of water. Mediums were allocated to sildenafil citrate $\left(10^{-4} \mathrm{M}\right)$, acetylcholine $\left(10^{-5} \mathrm{M}\right)$ and sodium nitroprusside $\left(10^{-6} \mathrm{M}\right)$. The upper end of each strip was suspended from an isometric force transducer, which was linked to an amplifier and a computerized chart recorder (TDA 97, Polygraph Systems, FDT10-A isometric transducer). The initial resting tension of each strip was at $2 \mathrm{~g}$ and the tissues were allowed to equilibrate for $60 \mathrm{~min}$ (Gocmen et.al. 1998; Shi et al. 2000). Two rings of a. brachialis were obtained from each animal. Totally, 16 a. brachialis rings were used. Sildenafil citrate was obtained from Pfizer, the other chemicals were obtained from Sigma.

\section{Statistical analysis}

Data were analyzed using a software (Polwin 97, MAY; Su mbuloglu and Sumbuloglu 1998). Mean of the negative logarithmic concentrations causing 50\% inhibition of the maximum contraction was expressed as $\mathrm{pD} 2$. The relaxations are expressed as a relative percentage decrease in tension induced by phenylephrine. Results were reported as mean \pm S.E.M. Significance was assessed by Student's- $t$ test for paired and unpaired values. Probability of less than 0.05 was considered to be significant.

\section{Results}

Experiment I: Microscopic findings

On day 3 , the wound area was filled with fibrin exudate including necrotic cells and neutrophil leukocytes in treated group, whereas, neutrophil leukocytes were more dominant in control group (Plate XI, Figs 1, 2). 
On day 6, compared to control group, there was an increase in the granulation tissue, which was composed of appearent capillar vessels and proliferation of fibroblast, in treatment group (Plate XII, Figs 3, 4).

On day 9, granulation tissue and capillar vessel proliferation were well formed in treated group, whereas, neutrophil leukocytes intfiltration in the granulation tissue in control group (Plate XIII, Figs 5, 6).

Experiment II: Effects of sildenafil citrate on isolated a. brachial strips

A. brachialis strips were relaxed by sildenafil citrate. The relaxating effect of sildenafil citrate was lower than that of acetylcholine and sodium nitroprusside $(p<0.001)$. Vasorelaxant effects for sildenafil citrate, acetylcholine and sodium nitroprusside were $4.91 \pm 0.16$, $5.75 \pm 0.04$ and $6.70 \pm 0.05$, respectively, on phenylephrine precontracted a. brachialis.

\section{Discussion}

Wound healing is regulated by locally produced mitogens and chemotactic factors. The process is composed of at least three crucial cellular events: movements of inflammatory cells and fibroblasia into the wound side; formation of granulosa tissue consisting of newly extracellular matrix and microvasculature and proliferation of cells native to the tissue.

Angiogenesis is an important indication for the healing process (Folkman and Shing 1992). Numerous agents including growth factors have been suggested to accelarete the healing process (Hughes and Hall 1993; Brown et al. 1988; Buckley et al. 1985). However, of these, growth factors accelarete healing process without altering angiogenesis (Kornowski et al. 2000). Contrary to this, some researchers suggested that the growth factors were not effective in wound healing (Lynch et al 1989; Van et al. 2001). Also, administration of growth factors is not feasible duo to limitation of delivery to target tissue (Efron et al. 2000). Sildenafil citrate is selective for PDE5 (Anon. 1998). In this study, giving sildenafil citrate orally,vasodilatation has been caused. Gocmen et al. (1998) reported that sodium nitroprusside is a very good vasorelaxant agent in mice. In the present study, although relaxant effect of sildenafil citrate was lower than that of acetylcholine and sodium nitroprusside $(p<0.001)$, sildenafil can be considered as a convenient vasorelaxant.

Chitin and chitosan, however, accelarete the healing process by stimulating the PMN and $\mathrm{MN}$ cells as well as accelerating growth of granulosa tissue along with providing abundant neovasculature structure (Leibovich et al. 1994). Okomato et al. (1992) suggest that exuberant granulation tissue has seen in the continious application of chitosan to the wounded animals. However, exuberant granulation tissue was not seen in experimental group in this study. The occurrence of edema in wound is a strong predictor of the angiogenegic response (B en Ezra 1998). In this study, edema was seen in the surrounding tissue on day 3 in experimental group, and it was seen on day 6 in control group.

There is much evidence to show that tissue oxygen tension and blood perfusion (Jon s s on et al. 1991), and the presence of PMN and MN cells in wounded area (Swaim et al. 1996; Hakkinen 1990) influences the wound healing. Oxygen is required for the hydroxylation of proline and lysine residues in the polypeptide chain assembled in the cytoplasm of the fibroblast. The helical procollagen molecule is not formed and is not subsequently released in to the extracellular space without enough oxygen. Vitamin $\mathrm{C}$ is also required for these hydroxylations. The source of these demands in the wound is the newly forming vasculature from the wound edge (Ringler 1997). In the present study, throught the experimental period, sildenafil citrate enhanced proliferation of new capillaries by its vasorelaxant effects. It is therefore inferred that the supply of oxygen, Vit. C, PMN and MN cells migrations could increase by sildenafil citrate administration in early phase of wound healing, resulting in shorter time in wound healing. 
Results of the present experiment indicated that sildenafil citrate could be used as a supporting factor in wound healing.

\section{Vliv sildenafil citrátu (Viagra) na časnou fázi procesu hojení otevřených ran u psů}

$\mathrm{V}$ pokusech in vivo $(\mathrm{n}=16)$ a in vitro $(\mathrm{n}=16)$ byly oveřrovány vlivy sildenafil citrátu (viagra) na patohistologické změny $\mathrm{v}$ průběhu procesu hojení na angiogenezi a byly srovnávány vazodilatační vlivy sildenafil citrátu, acetylcholinu a Na-nitroprussidu u psủ. Intravenózní anestezie pomocí $0,2 \%$ ketaminu $\mathrm{HCl}$ byla provedena po premedikaci xylazinem $\left(5 \mathrm{mg} \cdot \mathrm{kg}^{-1}\right)$ a atropin sulfátem $\left(0.05 \mathrm{mg} \cdot \mathrm{kg}^{-1}\right)$. Oválné otevřené rány byly vytvořeny přes všechny vrstvy kủže $\mathrm{v}$ předloktí. V 1., 3., 5. a 7. dnu po operaci byl orálně podán sildenafil citrát $\mathrm{v}$ dávce $25 \mathrm{mg}(\mathrm{n}=8)$ anebo fyziologický roztok $(\mathrm{n}=8)$. Vzorky $\mathrm{z}$ tkáně z ran byly odebrány $\mathrm{k}$ histologickému vyšetření 3., 6. a 9. dne po operaci. Zviřata, kterým byl podáván sildenafil citrát měla 6 . dne více granulující tkáně, žretelnější kapilární sít a proliferaci fibroblastů než kontrolní skupina . Vasorelaxační účinky sildenafil citrátu, acetylcholinu a Na-nitroprussidu na a. brachialis byly studovány in vitro. Relativní vazodilatační efekty těchto látek byly $4,91,5,75$ a 6,70 . Výsledky studie naznačují, že sildenafil citrát podporuje proces hojení ran stimulací angiogeneze.

\section{References}

ANONYMOUS 1988: Viagra, Pfizer Inc.,USA.

BEN EZRA, O 1998: Critical assesment of in vitro and in vivo assays of angiogenesis. In: Maragoudakik M (Ed.): Models, Models and clinical applications. Plenum Press, New York. Pp. 85-89.

BROWN, LF, VAN DE WATER, L, HARVEY, VS, DUORAK, HF 1988: Fibrinogen influx and accumulation of cross-linked fibrin in healing wounds and in tumor stroma. Am J Pathol 130: 455-465

BUCKLEY, A, DAVIDSON, JM, KAMERATH, CD, WOLT, TB, WOODWARD, SC 1985: Sustained release of epidermal growth factor accelerates wound repair. Proc Natl Acad Sci USA 82: 7340-7344

EFRON, DT, MOST, D, SHI, HP, TANTRY, US, BARBUL, A 2001: A novel method of studying wound healing. J Surg Res 98: 16-20

FOLKMAN, M, SHING, Y 1992: Angiogenesis. J Biol Chem 267: 10931-10934

GOÇMEN, C, SECILMIS, A, UCAR, P, KARATAS, Y, ONDER, S, DIKMEN, A, BAYSAL F 1998: A possible role of S-nitrosothiols at the nitrogenic relaxations in the mouse corpus cavernosum. Eur J Pharmacol 361: 8592

HAKKINEN, L 1990: Fibroblast-bioactive glass interactions. In: YAMAMURO, T, HENCH, HUGHES, SE, HALL, PA 1993: Overview of the fibroblast growth factor and receptor families: complexity, funtional diversity and implications for future cardiovascular research. Cardiovasc Res 27: 1199-1203

JONSSON, K, JENSEN, JA, GOODSON, WH, SCHEUENSTUHL, H, WEST, J, HOPF, HW, HUNT, TK 1991: Tissue oxygenation, anemia, and perfusion in relation to wound healing in surgical patients. Ann Surg 214: 605613

KORNOWSKI, R, FUCHS, S, LEON, M, EPSTEIN, SE 2000: Delivery Strategies to achieve therapeutic myocardial angiogenesis. Circulation 101: 454-458

LEIBOVICH, SJ, POLVERINI, PJ, FONG, TW, HARLOW, LA, KOCH, AE 1994: Production of angiogenic activity by human monocytes requires an $\mathrm{L}$ arginine/nitric oxide-synthase-dependent effector mechanism. Proc Natl Acad Sci USA 91: 4190-4194

LYNCH, SE, COLVIN, RB, ANTONIADES, HN 1989: Growth factors in wound healing. J Clin Invest 84: 640646

OKAMOTO, Y, MINAMI, S, MATSUHASHI, A, SASHIWA, H, SAIMOTO, H, SHIGEMASA, Y, TANIGAWA, T, TANAKA, Y, TOKURA, S 1992: Application of chitin and chitosan in small animals. In: SANDFORD, CJ, BRINE, PA, ZIKAKIS, JP (Eds.) Advances in chitin and chitosan. Elsevier Science. New York, pp. 70-78

RINGLER, DJ 1997: In: CARROLL, C. Veterinary Pathology. $6^{\text {th }}$ ed., MD, Williams and Wilkins. USA, pp. 113158

SHI, CC, CHEN, SY, WANG, GJ, LIAO, JF, CHEN, CF 2000: Vasorelaxant effects of harmon. Eur J Pharmacol 390: $319-325$

STEWART, AG, PHAN, LH, GRIGORIADIS, G 1994: Physiological and pathophysiological roles of nitric oxide. Microsurgery 15: 693-699

SUMBULOGLU, K, SUMBULOGLU, V 1998: Biyoistatistik, $8^{\text {th }}$ Ed. Hatibo?lu Yayınevi, Ankara, pp. 76-86 
SWAIM, SF, VAUGHN, DM, KINCAID, SA 1996: Effect of locally injected medications on healing of pad wounds in dogs. Am J Vet Res 57: 394-399

VAN ROYEN, N, PIEK, JJ, BUSCHMANN, I, HOEFER, I, VOSKUIL, M, SCHAPER, W 2001: Stimulation of arteriogenesis; a new concept for the treatment of arterial occlusive disease. Cardiovascular Res 49: 543-553

ZICHE, M, MORBIDELLI, L, MASINI, E, AMERINI, S, GRANGE, HJ, MAGGI, CA 1994: Nitric-oxide mediates angiogenesis in vivo and endothelial cell growth and migration in vitro promoted by substance $\mathrm{P}$. J Clin Invest 94: 2036-2044 


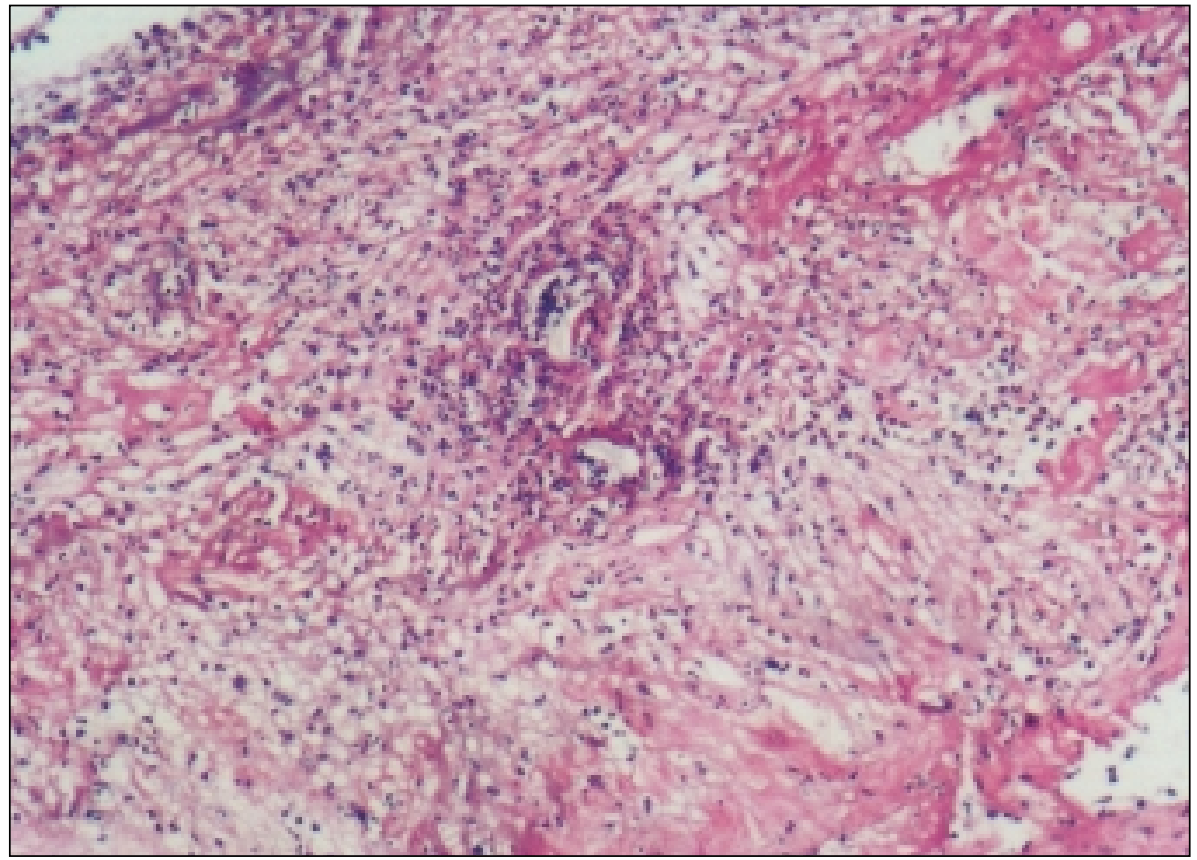

Fig.1. Day 3 of the experiment. Neutrophil leukocytes and necrotic cells in fibrin exsudate. HE $¥ 400$.

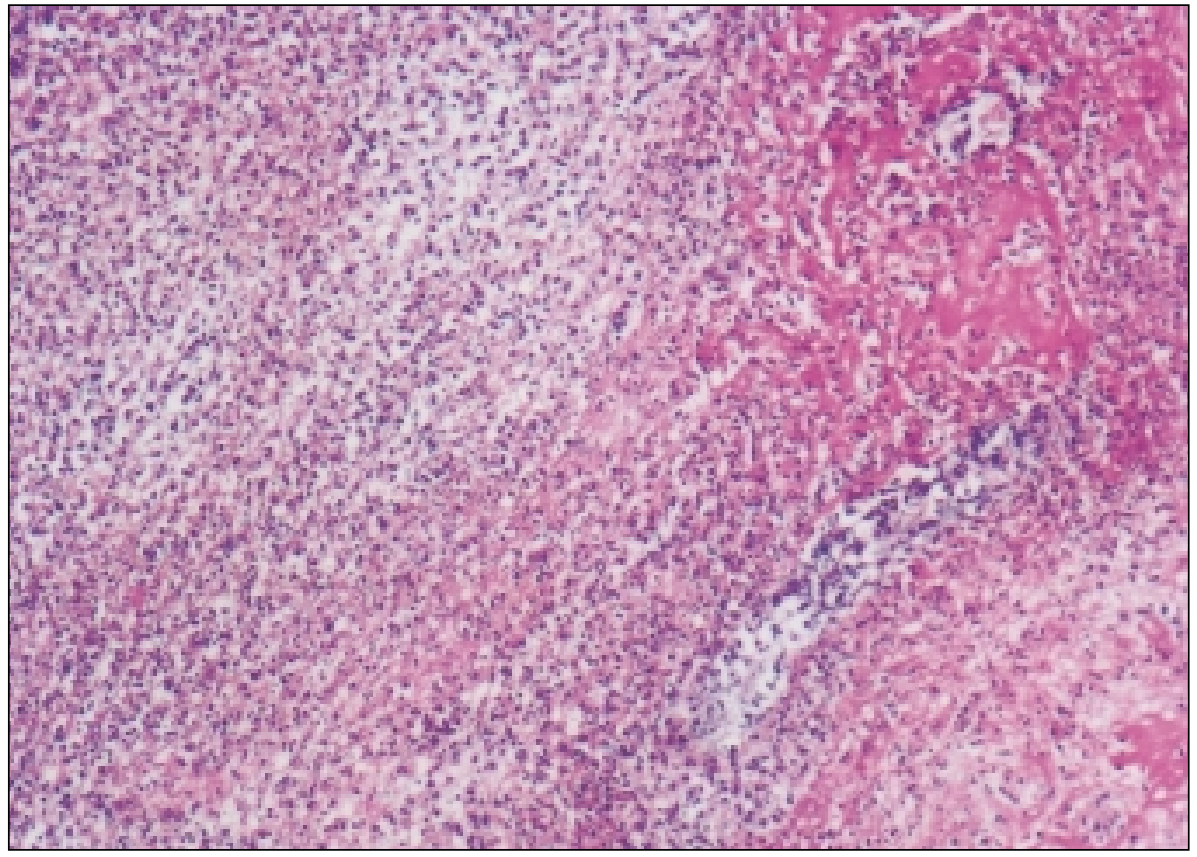

Fig. 2. Day 3 of control. Neutrophil leukocytes and necrotic cells in fibrin exsudate. HE $¥ 200$. 


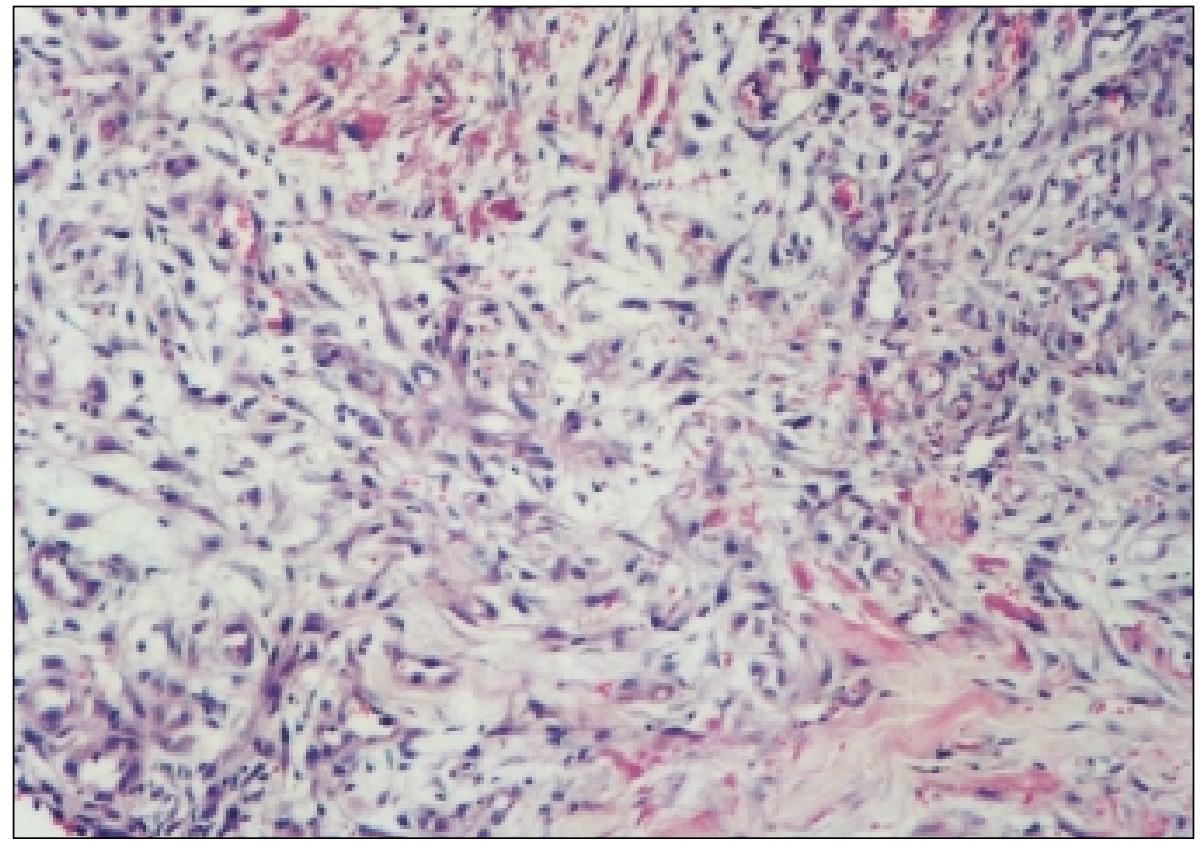

Fig 3. Day 6 of the experiment. New capillar vessel proliferations opening to the circulation and collagen in wound area. HE $¥ 200$.

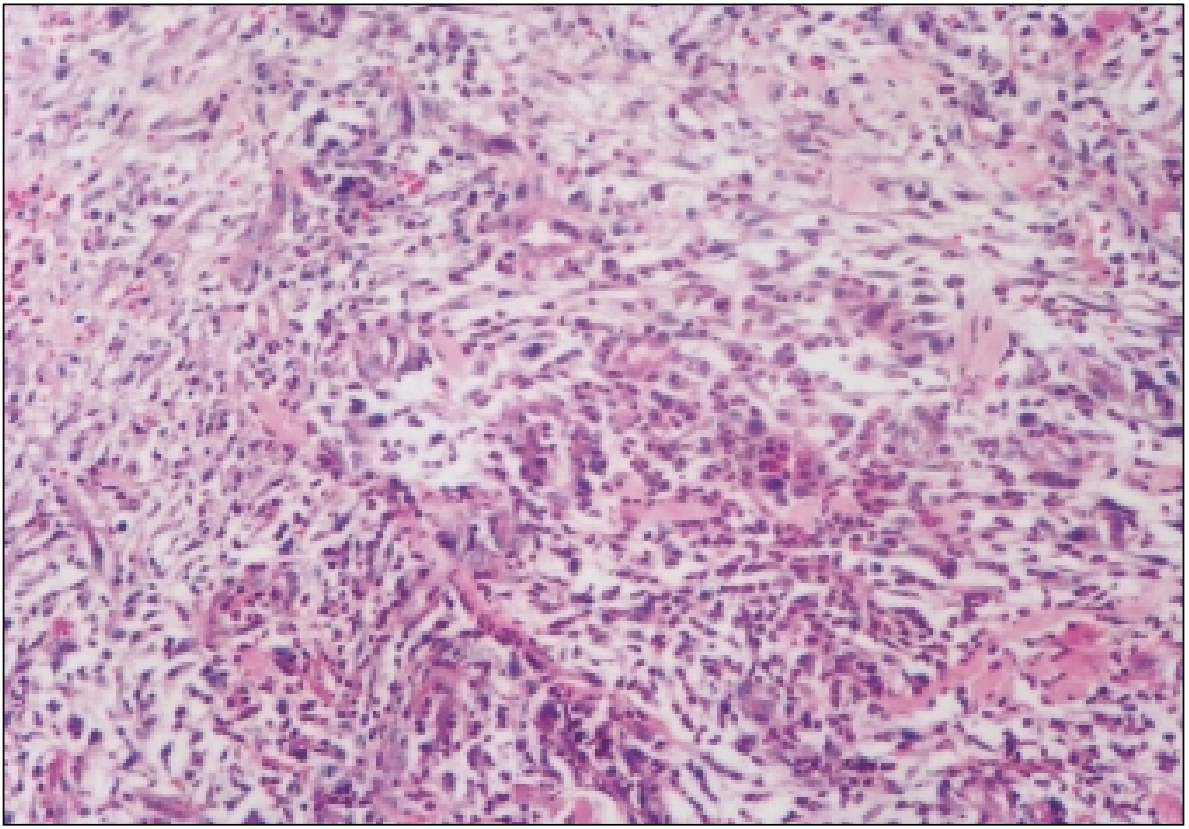

Fig 4. Day 6 of control. Collagen and capillar vessel proliferation formation in a less degree in wound area. HE $¥ 200$. 


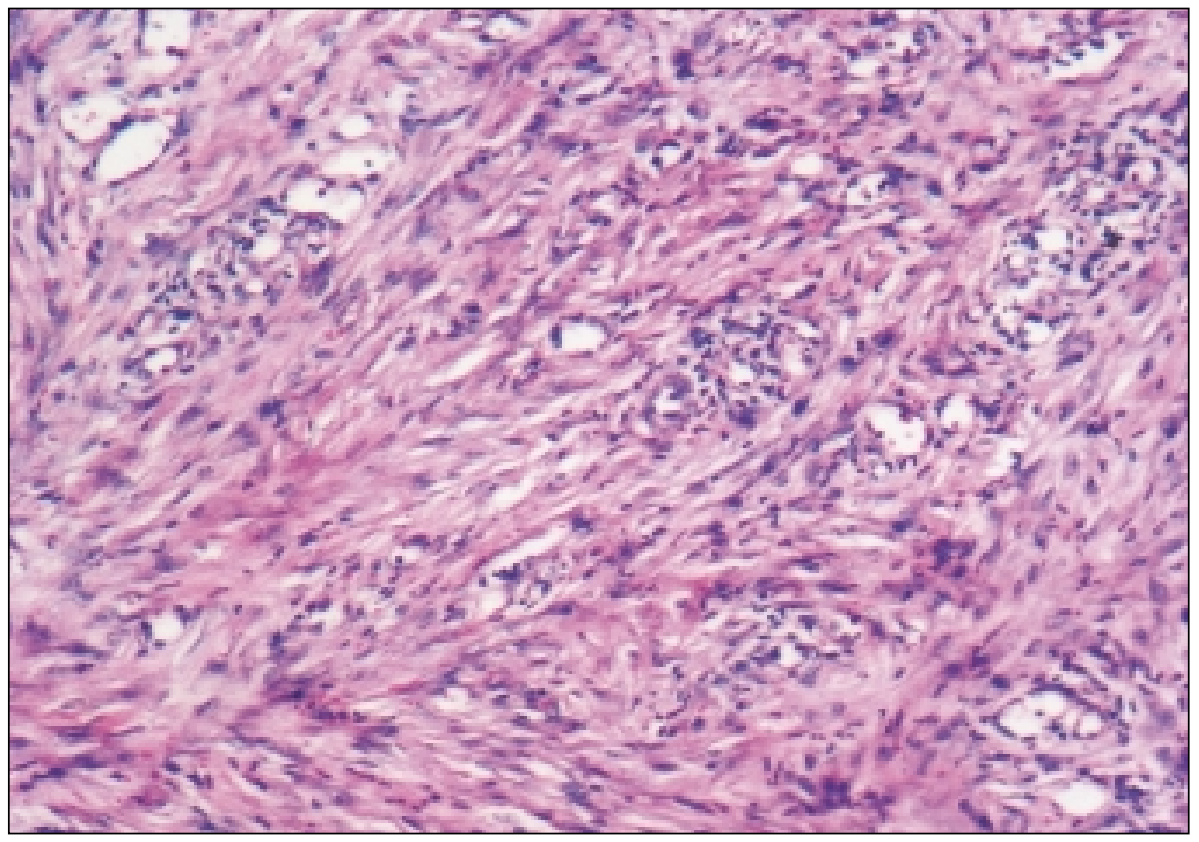

Fig 5. Day 9 of the experiment. The formation of granulation tissue with mononuclear cell infiltration and vasculirization. HE $¥ 200$.

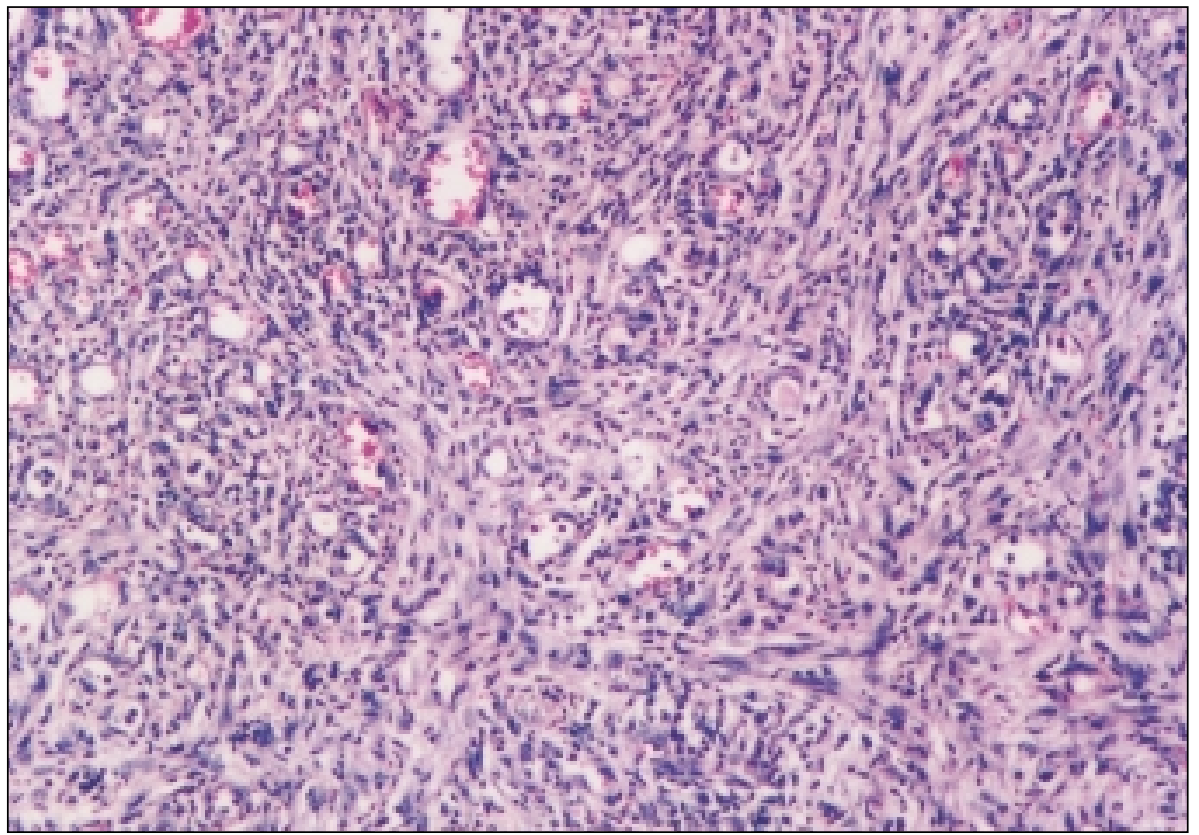

Fig 6. Day 9 of control. Proliferation of granulation tissue and prominent neutrophil leukocyte infiltration. HE $¥ 200$. 
